\title{
Chlorinated Pyridazin-3-(2H)-ones as Novel Anti-Cancer Agents
}

\author{
Lattmann $E^{*}$, Low F, Singh H, Tisdale MJ and Kinchinaton D \\ The School of Pharmacy, Aston University, Aston Triangle, Birmingham B4 7ET, UK
}

*Corresponding author: Eric Lattmann, The School of Pharmacy, Aston University, Aston Triangle, Birmingham B4 7ET, UK, Fax: +44(0)121 359 0733, E-mail: e.lattmann@aston.ac.uk

Citation: Lattmann E, Low F, Singh H, Tisdale MJ, Kinchinaton D (2014) Chlorinated pyridazin-3-(2H) ones as novel anti-cancer agents. SAJ Cancer Sci 1: 102. doi: 10.18875/2375-6683.1.102

Article history: Received: 18 June 2014, Accepted: 03 September 2015, Published: 04 September 2014

\begin{abstract}
Analogues of new lead structures, such as amido-2(5H)-furanones, bisarylated acrylic acids and 3(2H)-pyridazones, were prepared from mucochloric acid. Initially, these simple butenolides and analogues have been evaluated in tissue culture studies and subsequently, selected examples were tested in vivo on MAC 16 murine colon cancer cell lines. Bis-arylated methacrylic acids showed in addition to a moderate cytotoxicity an inhibition of tumor growth in vivo in mice. The xylene derivative MXAA displayed at $20 \mathrm{mg} / \mathrm{kg}$ a $25 \%$ inhibition compared to $27 \%$ for the control (5-FU). The acetamido-furanone AAF displayed an IC50 of 18, $4 \mu \mathrm{M}$ for the MAC 13 and MAC16 cell line, respectively and this translated into $26 \%$ inhibition of tumour growth in the transplanted MAC 16 cell line in mice. The unsubstituted pyridazine DCPYR, had a manifold higher in vitro activity, than the known arylated pyridazones and most interestingly this correlated well with the observed in vivo activity. Pyridazine DCPYR showed 53\% inhibition of tumour growths in vivo in mice at a $50 \mathrm{mg} / \mathrm{kg}$ dose and less weight loss was observed for this best agent compared to the anti-metabolite 5-FU, which served as standard.
\end{abstract}

Keywords: Computed tomography; Cone-beam computed tomography; Radiation dose; Cancer risk; Personalized imaging

\section{Introduction}

Many cancer patients have metastatic disease at diagnosis and cannot be cured by modern cancer treatment. There are tumours, for example those of the testes, choriocarcinomas and Hodgkin's disease, that are now curable, even at an advanced stage. Some other tumours for example in the lung, breast, and prostate may show considerable benefit from chemotherapy or hormonal manipulation. Cancer suspect agents like epoxides, aziridines and N-nitroso compounds [1] served as a starting point for the development of anti-cancer agents in the past. Alkylating agents such as Chlorambucil and Cyclophosphamide, which are still in clinical use, contain reactive chlorine atoms as leaving groups [2]. Various butenolides such as Penicillin acid [3] and Basidalin [4] are furanone based natural products [5] and exhibit antitumour activity in the micromolar range. Cis platinum compounds, useful agents in the treatment of testicle cancer, display a structural similarity with the dichlorinated derivatives of this research [6]. Penicillin acid is a cytotoxic agent and uracil, as well as tymine, are pyrimidin based nucluotides, whose best known analogue 5-fluorouracil, 5-FU, is a standard anticancer agent (anti-metabolite). Uracil, the pyridinone based template and the optimized pyridazine lead structure are outlined in Figure 1. Thus, we designed a potential anti-metabolite with alkylating properties, an azaanalogue of uracil containing chemically reactive chlorine.

Initial findings on the synthesis of novel 3,4-dihalogenated 5-substituted 2(5H)-furanones [7,8] were reported and arylated pyridazines were evaluated as potential anticancer agents $[9,10]$. The synthesis and evaluation of anticancer butenolides from dichloroacetyl chloride and NMF was published in a granted patent showing the principal usefulness of these agents [11]. The one pot synthesis was the starting point towards these lead structures [12] which provided intermediates and lead structures for SAR optimization and the preparation of aza-analogues. The lead structures were synthesized by alternative chemical routes and these novel analogues were subsequently evaluated in vitro in cell culture assays and in vivo in mice. 
<smiles>O=c1cc[nH]c(=O)[nH]1</smiles><smiles>CN1C(=O)C(Cl)=C(Cl)C(=O)C1O</smiles><smiles>O=c1[nH]ncc(Cl)c1Cl</smiles>

Figure 1: Uracil, the original pyridinone lead structure and the optimized pyridazine

\section{Materials and Methods}

\section{Chemistry}

Chemicals: Muco chloric acid was obtained from Lancaster Ltd (Lancaster, UK). All the other reagents were purchased from Aldrich, UK.

General: Atmospheric pressure chemical ionisation mass spectrometry (APCI-MS) was carried out on a Hewlett-Packard 5989B quadrupole instrument connected to an APCI accessory. IR spectra were recorded as $\mathrm{KBr}$ discs or in chloroform on a Mattson 3000 FT-IR spectrophotometer. Nuclear Magnetic Resonance spectra were obtained on a Bruker AC 250 instrument with TMS as internal standard.

\section{2,3-Dichloro-4,4-bis(2,4-dimethylphenyl)but-2-enoic acid MXAA}

$8.19 \mathrm{~g}(48.5 \mathrm{mmol})$ mucochloric acid was dissolved in $200 \mathrm{ml}$ of m-xylene. $10 \mathrm{~g}$ powdered aluminium chloride was added slowly to the resultant solution, capped with a drying tube and the mixture was stirred for $72 \mathrm{hrs}$. The crude product was poured into a beaker containing $125 \mathrm{~g}$ ice and $38 \mathrm{~g}$ concentrated $\mathrm{HCl}$. The organic phase separated from the aqueous phase by extraction using toluene. The resulting solution was dried over magnesium sulphate, the solvent was removed under vacuum and the product was dried under vacuum in a dedicator.

Yield = 85\%; $\mathrm{C}_{20} \mathrm{H}_{20} \mathrm{Cl}_{2} \mathrm{O}_{2}$; Molecular Weight: 363.28; APCI+ M/S: 326/327. EI MS: m/z = 2362/364 (M+), 326, 291, 247, $232,215$. IR: $v=2969,2925,2865,2649,1730,1693 \mathrm{~cm}^{-1} .{ }^{1} \mathrm{H}-\mathrm{NMR}\left(\mathrm{CDCl}_{3}\right): \delta=7.01-6.88(\mathrm{~m}, 6 \mathrm{H}, \operatorname{aryl}-\mathrm{H}), 6.62\left(\mathrm{~s},{ }^{1} \mathrm{H}, \mathrm{CH}\right), 2.31(\mathrm{~s}, 6 \mathrm{H}$, o- $\left.\mathrm{CH}_{3}\right), 2.11$ (s, $\left.6 \mathrm{H}, \mathrm{p}-\mathrm{CH}_{3}\right) \mathrm{ppm}$ (carboxylic acid group not detectable).

${ }^{13} \mathrm{C}-\mathrm{NMR}\left(\mathrm{CDCl}_{3}\right): \delta=166.41(\mathrm{COOH}), 155.23(\mathrm{ClCCH}), 136.83 \& 136.35 \& 135.62 \& 131.21 \& 128.29$ \&126.63 (aryl-C), 122.36 $(\mathrm{CCOOH}), 49.02(\mathrm{CH}), 20.95\left(\operatorname{aryl}-\mathrm{CH}_{3}\right), 19.22\left(\operatorname{aryl}-\mathrm{CH}_{3}\right) \mathrm{ppm}$.

\section{Preparation of Dichloro-5-oxo-2,5-dihydro-furan-2-yl-acetamides}

Method: Dry mucochloric acid $(15.0 \mathrm{~g}, 88.8 \mathrm{mmol})$ and 3 equivalents of $\mathrm{N}$-methylformamide/acetamide $(287 \mathrm{mmol})$ were refluxed in toluene $(100 \mathrm{ml})$ with $0.5 \%$ conc. $\mathrm{H}_{2} \mathrm{SO}_{4}$. TLC was used to monitor the progress of the reaction (ether/petrol ether). After 12 hours, silicagel was added until a light brown fine powder was obtained, which was extracted with a solvent mixture (20\% ether/ $80 \%$ petrol ether). The solvent was evaporated off under vacuum to give a pure crystalline compound.

Dichloro-5-oxo-2,5-dihydro-furan-2-yl)-N-methyl-acetamide AAF: Yield = 31\%; M.P: 119-121 oC; Rf (10\% methanol / 90\% ether) = 0.37; MW: 224.0; Molecular Formula: $\mathrm{C}_{7} \mathrm{H}_{7} \mathrm{NO}_{3} \mathrm{Cl}_{2}$;MS (APCI (+)): 182/184/186 (M+1), 224/226/228 (M+) m/z; IR (KBrdisc) v max: 3436, 2949, 2843, 1787, 1663, 1631, 1397, 1314, 988, $745 \mathrm{~cm}^{-1}$; ${ }^{1} \mathrm{H}$ NMR $\left(\mathrm{CDCl}_{3}\right) 250 \mathrm{MHz}$ : $\delta=6.48(\mathrm{~s}, \mathrm{CH}), 2.69$ (s, N-CH $)_{3}$, $2.44\left(\right.$ s, $\left.\mathrm{CO}_{-} \mathrm{CH}_{3}\right)$ p.p.m. ${ }^{13} \mathrm{C} \mathrm{NMR}\left(\mathrm{CDCl}_{3}\right) 250 \mathrm{MHz}: \delta=172.4(\mathrm{~N}-\mathrm{CO}), 163.5(\mathrm{CO}), 148.1(\mathrm{CH}-\mathrm{C}-\mathrm{Cl}), 124.3(\mathrm{C}-\mathrm{Cl}), 83.4$ $(\mathrm{CH}), 29.1\left(\mathrm{~N}-\mathrm{CH}_{3}\right), 22.1\left(\mathrm{CO}-\mathrm{CH}_{3}\right)$ p.p.m.

3-4-dichloro-5-oxo-2,5-dihydrofuran-yl(methyl)-formamide $\mathrm{R}=\mathrm{H}$ : Yield: $20.5 \%$; $\mathrm{Rf}(10 \% \mathrm{MeOH} / \mathrm{ether})=0.53$; Mol. Formula: $\mathrm{C}_{6} \mathrm{H}_{5} \mathrm{Cl}_{2} \mathrm{NO}_{3}$. MW: 210; MS (APCI(+)): $210(\mathrm{M}+1) \mathrm{m} / \mathrm{z}$; IR (KBr-disc) $v$ max: 2961, 1806, 1701, 1408, 1299, 1030, 913, $747 \mathrm{~cm}^{-1} ;{ }^{1} \mathrm{H}$ NMR (DMSO-d 6 ) $300 \mathrm{~K} \delta$ : (Isomers) 2.60, $2.84\left(\mathrm{~s}, \mathrm{CH}_{3}\right.$ ), 6.22, 6.80 (s, CH), 8.37, 8.52 (s, COH) p.p.m. ${ }^{13} \mathrm{C}$ NMR (DMSO-d $) 300$ $\mathrm{K} \delta$ : (Isomers) 24.4, $28.3\left(\mathrm{CH}_{3}\right), 81.5,88.6(\mathrm{CH}), 124.0,124.9$ (C-Cl), 146.3, 147.1 (C-Cl-CO), 161.8, 162.5 (CO-O), 163.8, 167.4 $(\mathrm{C}=\mathrm{O})$ p.p.m.

\section{Preparation of 4,5-Dichloro-3-pyridazones}

4,5-Dichloro-2-p-methoxy-phenyl-3-pyridazone $\mathbf{R}=\mathbf{p}$-MeOPh: A solution of mucochloric acid (2.1g, $0.012 \mathrm{~mol}) \mathrm{in} \mathrm{methanol} /$ water $(1: 1,10 \mathrm{ml})$ was stirred at room temperature and a mixture of the p-methoxyphenyl-hydrazine hydrochloride $(0.016$ mol) in methanol/water $(1: 1,10 \mathrm{ml})$ was added drop wise and was reacted at room temperature. The uncyclized hydrazone precipitated out from this solution as an orange-brown solid, which was collected after $3 \mathrm{~h}$ by filtration. Glacial 
acetic acid was slowly added at $100-110^{\circ} \mathrm{C}$ to the hydrazone intermediate and the mixture was subsequently refluxed for 20 min. The solution was diluted with water and cooled on ice. On cooling the pyridazone adduct was obtained as beige, coloured powder. After recrystallization from $90 \%$ ethanol, a white powder was obtained (mp 176-177 $\left.{ }^{\circ} \mathrm{C}\right)$.

Yield: 39\%. MS-APCI (+): 273/275 (M+1) m/z; IR (KBr) cm²: 3049, 2924, 1818, 1655, 1572, 1241, 1136, 943, 807.

1HNMR $\left(\mathrm{CDCl}_{3}\right) 3.80(\mathrm{~s}, 3 \mathrm{H}, \mathrm{OMe}) ; 7.64+7.10(\mathrm{~d}, 2 \mathrm{H}+2 \mathrm{H}, \mathrm{Ar}-\mathrm{H}), 8.26(\mathrm{~s}, 1 \mathrm{H},-\mathrm{CH}) \mathrm{ppm} ;{ }^{13} \mathrm{CNMR}(\mathrm{CDCl} 3) \delta 60.34\left(p-\mathrm{OCH}_{3}\right)$ 126.4, 129.3, 134.3, 136.1 (Ar-C), 136.9, 137.1, 139.6, $154.2(\mathrm{C}=\mathrm{O}) \mathrm{ppm}$.

4,5-Dichloro-2-pyridazin-3(2H)-one DCPYR: A solution of muco chloric acid (2.1g, $0.012 \mathrm{~mol})$ in methanol/water (1:1, $10 \mathrm{ml})$ was stirred at room temperature. To this solution semicarbazide hydrochloride $(1.81 \mathrm{~g}, 0.016 \mathrm{~mol})$ in methanol/water $(1: 1,10 \mathrm{ml})$ was added drop wise and stirred for $20 \mathrm{~min}$ at room temperature. To the resultant precipitate, $10 \mathrm{ml}$ of acetic cid was added, and the reaction mixture was refluxed until the development of carbondioxide ceased (30 min). The solution was diluted with water and cooled. On cooling the pyridazone adduct was obtained as an off white powder. After recrystallization from $90 \%$ ethanol, a white crystalline powder was obtained ( $\left.\mathrm{mp} 202-203^{\circ} \mathrm{C}\right)$.

Yield: 73\%. MS-APCI (+): 276/278 (M+1) m/z; IR $(\mathrm{KBr}) \mathrm{cm}^{-1}: 3215,3030,1815,1633,1216,1142,1035,816 .{ }^{1} \mathrm{HNMR}\left(\mathrm{CDCl}_{3}\right) \delta$ 7.78-7.74 (m, 4H, Ar-H), 8.26 (s, 1H, -CH) ppm; ${ }^{13} \mathrm{CNMR}\left(\mathrm{CDCl}_{3}\right) \delta$ 128.4, 134.6, 134.8, 135.3, 136.9, 137.3, 143.6 (N-C-Ar), 159.6 $(\mathrm{C}=\mathrm{O}) \mathrm{ppm}$.

\section{Biological evaluation}

In vitro cytotoxicty The cytotoxicity was determined against the murine carcinoma cell lines (MAC13 and MAC16) using the standard MTT assay [13]. The culture media used was RPMI 1640 containing hepes, glutamine, antibiotics and supplemented with $10 \%$ fetal calf serum for MAC13 cells and 5\% fetal calf serum for MAC16 cells. Cells were counted by the trypan blue exclusion method using a plastic Kova counting chamber. The MAC13 and MAC16 cells were suspended in appropriate volumes of media and were seeded at $0.5 \times 10^{4}$ and $2 \times 10^{4}$ cells / $200 \mu \mathrm{l}$ respectively in flat-bottomed 96 well plates. The test compounds were dissolved in dimethyl sulphoxide (DMSO) to give stock solutions of $100 \mathrm{mM}$. Dilution series from $10^{-4} \mathrm{M}$ to $10^{-9}$ were made so that each compound was tested at six concentrations and in triplicate.

5-Fluoro-uridine (5-FU), a known anticancer agent, was used as a control and tested in the 20-0.02 $\mu \mathrm{M}$ range. Plates were then incubated at $37{ }^{\circ} \mathrm{C}, 5 \% \mathrm{CO}_{2}$ for three days. Compounds were tested on at least two separate occasions. On day three $20 \mu \mathrm{l}$ of 3-(4,5-dimethylthiazol-2-yl)-2,5-diphenyl-tetrazolium bromide (MTT) (7.5mg MTT /ml of PBS) was added to each well and plates were allowed to incubate for a further $2 \mathrm{~h} .120 \mu \mathrm{l}$ of culture supernatant was carefully removed from each well and $100 \mu \mathrm{l}$ of acidified i-propanol containing 10\% Triton-X100 was then added to each well. Plates were agitated for 10 minutes at $800 \mathrm{rpm}$ on a plate shaker. Following this solubilisation step all plates were then read, within 15 minutes, on an Anthos AW200 plate reader at $540 \mathrm{~nm}$ with a reference wavelength of $590 \mathrm{~nm}$.

\section{In vivo experiments in mice - assessment of anti-tumour inhibition}

Pure strain NMRI mice aged between 6 and 8 weeks from our inbred colony were used for transplanting MAC (murine colon cancer) tumours. Animals were fed on RM3E diet (Lillco-England) and water ad libitum. Approximately $2 \mathrm{~mm}$ cubes containing $2 \times 10^{5}$ cells of MAC 16 tumour fragments were transplanted subcutaneously in the inguinal region via a trocar in a volume of $0.2 \mathrm{ml}$. Tumour bearing mice were randomised in groups of 7 animals per group and the treatment was started 10 days after transplantation. The test compounds were administered in propylene glycol. The effect of chemotherapy was assessed 20 days after transplantation. Mice were killed after 10 days of drug treatment and the effects were measured by the differences in tumour weight as expressed:

$$
\% \text { [inhibition] }=\text { Treated weight } / \text { control weight } \mathrm{x} 10
$$

The body weight changes were recorded additionally. The procedure was approved by the home office and the bioethics committee of Aston University.

The results are expressed as mean \pm S.D. and the data were subjected to repeated measures of the one-way analysis of variance (ANOWA). If the probability level (p-value) is less than 0.05 , a statistical significance was attained.

\section{Results and discussion}

\section{Chemistry of the lead structures}

NMF and dichloroacetyl chloride formed the expected amide I. Loss of CO, addition of a second molecule of dichloroacetyl chloride formed the lactone ring system in a 5-exo-trig reaction leading towards the amidofuranone via a dichloro-methacrylic acid intermediate. In presence of base the methacrylic acid derivative cyclised into the 7-membered ring intermediate, which reacted in situ in a retro-Bayer-Villiger rearrangement into the desired dihydropyridone (Pyrroldione lead structure). 
<smiles>CNC=O</smiles>

NMF
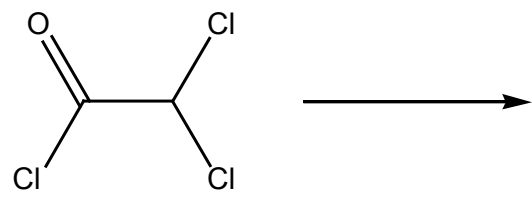

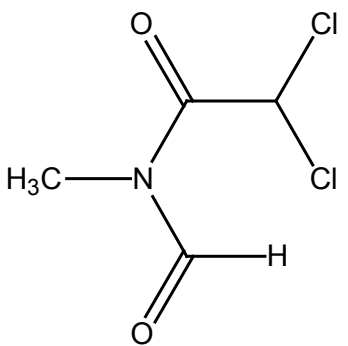

Amide

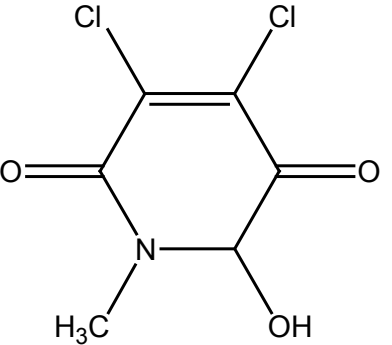

Pyridindione

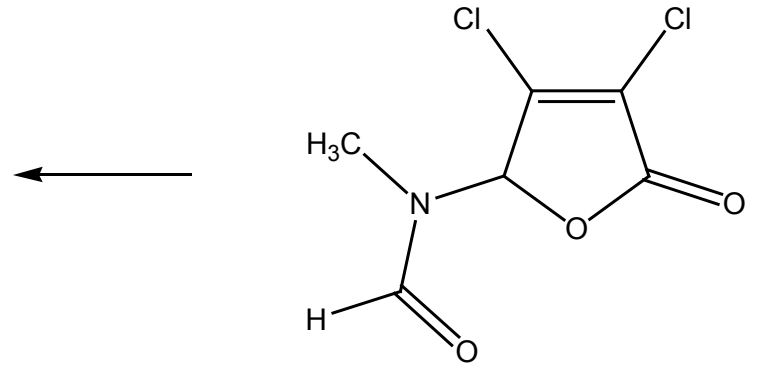

Amidofuranone

Figure 2: Lead structure discovery from NMF to a the antineoplastic lead structures

The structural similarities of the lead structure with the nucleotides, outlined in figure 1, are recognized in addition to the alkylating properties of the agents.

Overall, at least 2 lead structures with a molecular weight of 210 , served as starting point of the synthesis of structurally related analogues.

\section{Analogue synthesis}

The overall starting material is mucochloric acid, which is commercially available form furfural [14]. Furfural is cheaper than DCM, dichloromethane, and it is available from biomass in unlimited quantities. Therefore, any synthetic application of furfural is an example of green chemistry, in which petrochemical intermediates were replaced by raw materials from biomass. Dichlorinated bis-arylated acrylic acids were derived from mucochloric acid in excess of xylene in presence of aluminum chloride as Lewis acid in very good yields. Toluene formed a mixture of the bisarylated acid, and the 5-arylfuranone [16].

A series of amido-furanones were formed from mucochloric acid, by refluxing the parent amide in toluene. Thus, the formamidoanalogue of the original lead structure $\mathrm{R}=\mathrm{H}$, with the molecular weight of 210 , was synthesized by an alternative route. Purification of the amido-furanone series was performed by column chromatography, which was essential in order to remove the pyrrol-diones by-products [15].

The desired pyridazones were synthesised most preferred in two steps from muco chloric acid [17]. The parent phenylhydrazine and semicarbazide were used to prepare hydrazone/semicarbazone intermediates and controlled cyclisation furnished the pyridazones as crystalline materials in high yields. The semicarbazide method was superior to the previous synthesis of DCPYR using hydrazine, which gave the desired product only in low yield [18].

\section{Pharmacology, in vitro - in vivo - evaluation}

The in vitro screening results, based on the MTT assay are outlined in Table 1 for the selected murine colon adenocarcinoma MAC 13 and the MAC 16 cell lines.

The determination of inhibition of tumour weight is a direct parameter in order to evaluate the anticancer properties of the agent. The evaluation of body weight is a second significant parameter in addition of the assessment of the tumour weight. 


\begin{tabular}{|c|c|c|c|c|}
\hline Entry & Structure & Yield (\%) & $\begin{array}{c}\text { MAC } 13 \\
\mathrm{IC}_{50}[\mu \mathrm{M}]\end{array}$ & $\begin{array}{l}\text { MAC } 16 \\
\mathrm{IC}_{50}[\mu \mathrm{M}]\end{array}$ \\
\hline MCA & Muco chloric acid & & $>100$ & $>100$ \\
\hline MXAA & Acrylic acid & 85 & $50 \pm 3$ & $70 \pm 5$ \\
\hline AAF & Amido-furanone & 31 & $18 \pm 3$ & $4 \pm 2$ \\
\hline $\mathrm{R}=\mathrm{H}$ & Amido-furanone & 20 & $17 \pm 1$ & $11 \pm 1$ \\
\hline Aryl & Pyridazine & 39 & $17 \pm 2$ & $35 \pm 3$ \\
\hline DCPYR & Pyridazine & 73 & $7 \pm 0.6$ & $5 \pm 0.4$ \\
\hline
\end{tabular}

Table 1: In vitro activity / cytotoxicity of synthesized analogues

A characteristic of the solid MAC16 tumour is the induction of weight loss in mice, which is reduced by an antineoplastic agent. Acute toxicity increased the weight loss above the level, which is caused by the MAC 16 tumour.

Analogues of methacrylic acid [19] derived from mucochloric acid exhibited cancer-modulating properties. The $20 \mathrm{mg} / \mathrm{kg}$ dose of derivative MXAA occured a 25\% tumour inhibition, comparable with the 5-FU standard, but the lower dose (10mg/kg) failed to prevent weight loss associated with the MAC16 cell line (Table 2).

The amido-furanones were found in vitro active in the micromolar range and for AAF selectivity towards the MAC 16 cell line was determined in vitro (Table 1). The antineoplastic effect of the $50 \mathrm{mg} / \mathrm{kg}$ dose of AAF is similar in vivo to the 5 -FU standard. It was analysed additionally by x-ray crystallography (Figure 3 ).

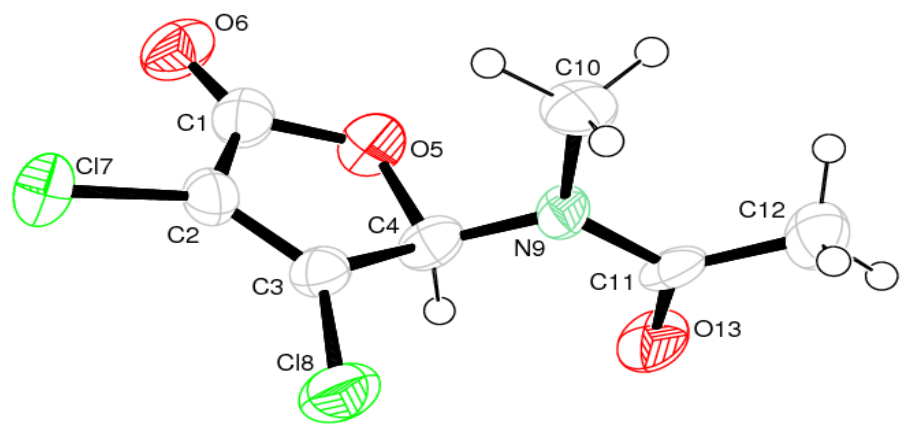

Figure 3: Crystal structure of N-(3,4-Dichloro-5-oxo-2,5-dihydro-furan-2-yl)-N-methyl-acetamide AAF.

The pyridazone DCPYR (Scheme 1) differs in one nitrogen atom from the original pyridindione lead structure (Figure 1), but the unsaturated di-chloro-moiety was maintained. Only the unsubstituted pyridazine $(\mathrm{R}=\mathrm{H})$ analogue DCPYR showed a remarkable in vitro inhibition, which was found 7 times higher than the arylated analogue for the MAC16 cell line (Table 1).

In vivo in mice more than $50 \%$ inhibition of tumor growth was found for the $50 \mathrm{mg} / \mathrm{kg}$ dose and this inhibition of tumour growths correlated well with the inhibition of MAC16 induced weight loss (Table 2) [20].

This strong antineoplastic action may be due to a dual acting mechanism, in which the derivative may act as anti-metabolite with alkylating properties. The dichloropyridazine DCPYR contains an unsaturated system with chemical reactive chlorine that is prone to nucleophilic substitution (alkylating agent).

\begin{tabular}{|c|c|c|c|c|}
\hline Entry & $\begin{array}{c}\text { Administration } \\
(\mathbf{m g} / \mathbf{k g})\end{array}$ & $\begin{array}{c}\text { Tumor } \\
\text { Inhibition } \\
(\%)\end{array}$ & $\begin{array}{c}\text { Body-weight } \\
(\mathbf{g})\end{array}$ & $\begin{array}{c}\text { Treatment } \\
(\text { days })\end{array}$ \\
\hline Water & 0 & - & $+0.1 \pm 0.05$ & $1-10$ \\
\hline \multirow{2}{*}{ MXAA } & 10 & $14 \pm 2.1$ & $-2.3 \pm 0.2$ & $1-7$ \\
& 20 & $25 \pm 2.6$ & $-1.3 \pm 0.3$ & $1-10$ \\
\hline & & & $-1.5 \pm 0.1$ & $1-10$ \\
\hline AAF & 50 & $26 \pm 1.5$ & & $-0.9 \pm 0.09$ \\
\hline DCPYR & 50 & $53 \pm 3.1$ & & $1-10$ \\
\hline
\end{tabular}

Route of administration: IP in propylene glycol

Table 2: In vivo data of selected molecules against MAC 16 cell lines 
MCA<smiles>O=C1OC(O)C(Cl)=C1Cl</smiles>

c<smiles>[R]C(=O)N(C)C1OC(=O)C(Cl)=C1Cl</smiles>

a

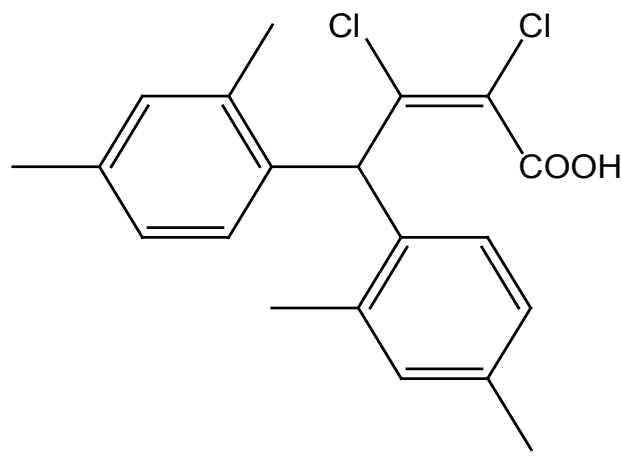

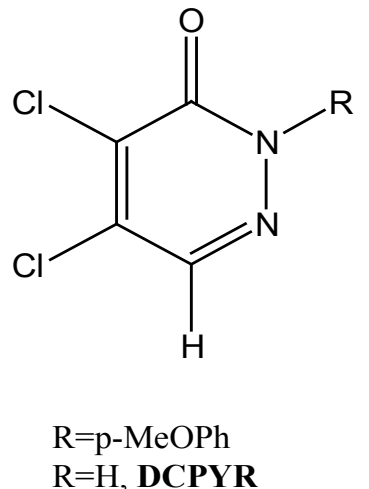

\section{MXAA}

Scheme 1: Synthesis of analogues

a) xylene, $\mathrm{AlCl}_{3}, \mathrm{RT}$ b) semicarbazide/hydrazine, $\mathrm{MeOH}$; reflux acetic acid

c) amide, toluene, reflux

\section{Conclusion}

3 novel lead structures (Scheme 2) were synthesized and subsequently the cytotoxicity of these molecules derived from mucochloric acid was determined in vitro and selected candidates were evaluated further in vivo in mice on the resistant MAC 16 cancer cell line.

The acetamido furanone AAF displayed a similar activity as the standard 5-FU.

The pyridazone DCPYR showed twice the tumour inhibition in vivo in just 10 days of treatment and no signs of acute toxicity were observed.

The molecule may act as an agent with at least dual action, an anti-metabolite and possibly alkylating agent.

Using semicarbazide, it can be prepared on a large scale to GMP standard and a full preclinical evaluation is justified.

\section{References}

1. Reynolds RC, Tiwary A, Harwell JE, Gordon DG, Garrett BD, et al. (2000) Synthesis and evaluation of several new (2-chloroethyl)nitrosocarbamates as potential anticancer agents. J Med Chem 43 1484-8.

2. Mutschler E (1996) Arzneimittelwirkungen, Pharmacology, 7th Edition. Wiss. Verl. Ges Stuttgart 749.

3. Black DK (1966) Synthesis of penicillin acid from 1-cysteine. J Chem. Soc 23: 1123-7.

4. Hiyama T, Oishi H, Suetsugu Y, Nishide K, Saimoto H (1987) Synthesis of 4-amino-2(5H)-furanones through intra- and intermolecular nitrile addition of ester enolates. Construction of carbon framework of an antitumor antibiotic. Bull Chem Soc Jpn 60: 2139-50.

5. Coombs J, Lattmann E, Hoffmann HMR (1998) Total Synthesis of Manoalide. Synthesis 1367-71.

6. Franco CM, Borde UP, Vijayakumar EK, Chatterjee S, Bulmbach J, et al. (1991) Butalactin a new butenolide antibiotic J Antibiotics 44: 225-31.

7. Lattmann E, Hoffmann HMR (1996) From tetronic acid and furfural to C(4)-halogenated, vinylated and formylated furan-2(5H)-ones and their 5-alkoxy derivatives. Synthesis 155-63. 
8. Lattmann E, Billington DC, Langley CA (1999) Synthesis of combinatorial libraries of 3,4,5-substitutes 2(5H)-furanones. Part two: Construction of a library of 4-amino-5-alkoxy-2(5H)-furanones. Drug Design and Discovery 16: 243-50.

9. Lattmann, E, Ayuko WO, Kinchinaton D, Langley CA, Singh H, et al. (2003) Synthesis and evaluation of 5-arylated 2(5H)-furanones and 2-arylated pyridazin3(2H)-ones as anticancer agents. J Pharm Pharmacol 55: 1259-65.

10. Lattmann E, Kinchington D, Dunn S, Singh H, Ayuko WO, et al. (2004) Cytotoxicity of 3,4 dihalogenated 2(5H)-furanones. J Pharm Pharmacol 55: 1163-70.

11. Ayuko WO, Lattmann E. Butenolide derivatives as anti-cancer agents. PCT/GB99GB 01074 UK patent, WO99/52888.

12. Ayuko WO, Tisdale MJ, Lattmann E. Antiproliferative agents. PCT/GB2373246; WO 02/07553.

13. Mosmann T (1983) Rapid colorimetric assay for cellular growth and survival: application to proliferation and cytotoxicity assays. J Immunol Methods 65: 55-63.

14. Mowry DT (1953) Mucochloric Acid. II. Reactions of the aldehyde group. J Am Chem Soc 1909-10.

15. Semonsky M, Rockowa E, Cerny A, Kakak B, Macek K (1962) Substances having an antineoplastic activity IV Some $\gamma$-aryl $\alpha$, $\beta$-substituted DELTA alpha, $\beta$ -crotonlactoneChem Comm 27: 1939-55.

16. Mowry DT (1950) Mucochloric Acid. I. Reactions of the pseudo acid group. J Am Chem Soc 2535-7.

17. Harwood LM, Moody CJ, Percy JM (1999) Experimental Organic Chemistry, Blackwell Science 609-11.

18. Cho SD, Choi WY, Yoon Y J (1996) Concurrent Alkylation of 4,5-dihalopyridazin-6-ones and synthesis of 5-halo-4-hydroxy-pyridazin-6-ones. J Heterocyclic Chem 33: 1579-82.

19. Semonský M, Rocková E, Cerný A, Kakác B, Macek K (1961) Substanzen mit antineoplastischer Wirksamkeit IV. Einige $\gamma$-Aryl- $\alpha$, $\beta$-Substituierte $\Delta^{\alpha, \beta}$-Crotolactone. Collection Czechoslov Chem Commun 27: 1939-54.

20. Howbert JJ, Crossman CS, Crowell TA, Rieder BJ, Harper RW, et al. (1990) Novel effective agents against solid tumors: The diarylsulfonylureas. J Med Chem 33: 2393-407. 